УДК 349.22

DOI https:/ / doi.org/10.32837/yuv.v0i5.2015

В. Клименко,

аспірант кафедри трудового права

Національного юридичного університету імені Ярослава Мудрого

\title{
ДО ПИТАННЯ КОМЕРЦІЙНОЇ ТАЕМНИЦІ У ТРУДОВИХ ВІДНОСИНАХ
}

Постановка проблеми. Зростання уваги та посилення практичного інтересу до питань, що стосуються трудового права в Україні, не $€$ випадковим, це зумовлено економічними, політичними й організаційно-правовими чинниками формування в Україні ринку праці, прагненням нашої держави інтегруватись у світовий простір та формувати законодавчу базу на основі стандартів Європейського Союзу. Одним із найбільш дискусійних та неоднобічних об'єктів трудових відносин $є$ комерційна таємниця.

Інститут комерційної таємниці отримав визнання в законах України «Про підприємства в Україні», «Про підприємництво», «Про інформацію», активно розвивається в цивільному та господарському праві, відповідні норми включено до Цивільного та Господарського кодексів (наприклад, у Цивільному кодексі України цьому інституту присвячено цілу главу). Водночас у контексті трудового права нічого подібного не спостерігається - нині чинне законодавство про працю не містить жодних норм щодо режиму використання комерційної таємниці чи відповідальності за іiі незаконне поширення. Натепер у законодавстві бракує низки принципових положень, які б нормативно закріпили порядок використання комерційної таємниці у трудових відносинах, до яких можна віднести обов'язок працівника зберігати в таємниці конфіденційну інформацію, заходи роботодавця з недопущення ii розголошення, типову форму договору про конфіденційність, алгоритм дій роботодавця в разі виявлення факту незаконного поширення комерційної таємниці, і найголовніше, можливість відшкодування збитків, завданих такою протиправною поведінкою працівника. Розгляд інституту комерційної таємниці саме в розрізі трудового права надасть змогу глибше, грунтовніше зрозуміти сутність комерційної таємниці та іï місце в економічній безпеці підприємства, принципову відмінність від інших видів інформації з обмеженим доступом.

Мета статті - розглянути комерційну таємницю в розрізі трудового права, зокрема визначити поняття та характерні ознаки цього інституту.

Аналіз останніх досліджень. Питання визначення поняття комерційної таємниці та іï ознак було предметом дослідження таких учених, як: Н. Вапнярчук, Ю. Капіца, Є. Краснов, Ю. Носік, О. Святоцький, Н. Северін, О. Середа, Д. Юсупова, О. Ярошенко й інші. У своїх працях більшість науковців розглядали комерційну таємницю як об'єкт господарських відносин та інтелектуальну власність підприємства, дослідженням же, присвяченим комерційній таємниці в контексті трудових відносин, приділялося мало уваги.

Виклад основного матеріалу. Під час дослідження комерційної таємниці у трудових відносинах насамперед закцентуємо увагу на загальній характеристиці цього явища. У наукових джерелах неодноразово 
робилися спроби надати визначення досліджуваному явищу, однак однозначного погляду натепер не існує. Так, Х. Кузнєцова в результаті проведеного аналізу вітчизняного і закордонного правового досвіду визначає комерційну таємницю як інформацію конфіденційного характеру, що прямо та безпосередньо пов'язана з підприємницькою діяльністю суб'єктів права на цю діяльність, як промислового (індустріального), так і торговельного характеру, або з діяльністю з надання послуг, що має реальну або потенційну економічну цінність та надає перевагу в конкурентній боротьбі через іi невизначеність, за розголошення якої настає юридична відповідальність, існує особливий режим і1 охорони [1, с. 204]. Комерційну таємницю також розглядають як: а) вид конфіденційної інформації, різновид інформації з обмеженим доступом [2, с. 41]; б) право підприємства, організації, банку на засекречування всіх виробничих, торговельних і фінансових операцій та відповідної документації, охоронюване законодавством [3, с. 795]; в) право на свободу підприємництва, захист своїх інтересів у відносинах із державою й іншими суб'єктами ринкових відносин [4, с. 261]; г) охоронюване законодавством право індивідуальних підприємців, комерційних і некомерційних організацій на засекречування відомостей про свою виробничу, економічну й фінансову діяльність, які, ставши відомими конкурентам або іншим стороннім особам, можуть завдати матеріальної та (або) моральної шкоди первісним власникам цих відомостей [5, с. 184].

Як бачимо, усі вищезазначені твердження характеризують комерційну таємницю як певне право: «Право на нерозголошення», «право на засекречування», «право на збереження в таємниці» тощо. Уважаємо, що комерційну таємницю не можна визначати суто як право, оскільки вона $€$ видом секретної інформації, право на яку має окремий суб'єкт господарювання. Отже, у змістовному плані комерційна таємниця може включати найрізноманітнішу економічну, технологічну, організаційну й іншу секретну інформацію, яка у процесі виконання службових обов'язків та з огляду на їхню специфіку доступна працівникові. Джерелом комерційної таємниці в контексті економічної безпеки підприємства $€$ внутрішні, насамперед бухгалтерські, документи компанії, а саме: відомості про обсяги товарообороту, перелік контрагентів, витрати на продаж, товарні записи, прибутки, роздрібна мережа, витрати на рекламу тощо. Навіть частковий витік такої інформації може призвести до суттєвих економічних потрясінь, навіть банкрутства компаніі. Ще одним джерелом комерційної таємниці $€$ дані зовнішньої статистики, які публікуються в засобах масової інформації, інформація про стан ринку. Останнім часом поширена купівля інформації в різних фірм, основним видом діяльності яких $€$ «виробництво і продаж чистої інформації» [6, с. 338].

Отже, комерційна таємниця - це економічні інтереси, що навмисно приховуються 3 економічних міркувань, відомості про різні сторони та сфери виробничо-господарської, управлінської, науково-технічної й фінансової діяльності фірми, охорона яких зумовлена інтересами конкуренції й можливими загрозами економічній безпеці компанії. Комерційна таємниця виникає тоді, коли вона становить інтерес для бізнесу [7, с. 315].

Продовжимо дослідження даного явища i проаналізуємо притаманні йому ознаки, бо без цього неможливо з'ясувати його правову природу. Так, Г. Андрощук і Л. Вороненко стверджують, що інформація, яку можна віднести до комерційної таємниці, повинна мати такі ознаки: а) не бути державними секретами (таємними даними); б) належати до торговельно-виробничої діяльності підприємства; в) не завдавати шкоди інтересам 
суспільства; г) мати дійсну або можливу комерційну цінність і створювати переваги в конкурентній боротьбі; г) мати встановлені володільцем інформації обмеження в доступі; д) ужиття останнім додаткових заходів для іï охорони [8, с. 14]. О. Святоцький виділяє такі характерні особливості комерційної таємниці: а) відповідні дані не належать до державної таємниці, не підпадають під охорону авторського права; б) неправомірне використання комерційної таємниці може спричинити негативні наслідки господарській та економічній діяльності підприємства; в) комерційна таємниця не може належати до суспільно шкідливої діяльності підприємства, що може завдати шкоди іншим особам чи соціуму загалом [9, с. 40, 41]. На думку Ю. Носіка, до ознак комерційної таємниці варто віднести: інформаційність, конфіденційність, комерційну цінність та захищеність інформації, яка становить комерційну таємницю [10, с. 172-177].

Отже, до характерних ознак комерційної таємниці, наявність яких може слугувати підставою для визначення інформації як комерційної таємниці та набуття відповідного правового захисту, а відсутність хоча б однієї 3 них ставить під сумнів існування спеціального режиму охорони, який діє суто за наявності сукупності всіх ознак, доцільно віднести такі: 1) це реальна або потенційна економічна цінність для суб'єкта господарювання через іï невідомість іншим учасникам ринку. Як наголошує С. Жилінський, інформація повинна бути не тільки новою, оригінальною, а й мати зараз реальну споживчу цінність чи набути такої в майбутньому, тобто стати нематеріальним активом, товаром; з огляду на інтерес з боку інших осіб може бути предметом господарських правочинів чи іншого обігу в економіці [5, с. 184]; б) обмежений доступ до неї. Інформацію варто вважати секретною доти, доки вона не стала загальновідомою чи доступною третім особам із відкритих джерел. Якщо шляхом аналітики й аналізу відкритої інформації, зразків товарів, порівняння різних об'єктів можна отримати інформацію, яку хтось уважатиме власною конфіденційною, то немає правових підстав для відповідного режиму захисту; в) встановлення власником механізму іï захисту, який може полягати в різнопланових діях організаційного, технічного чи юридичного характеру, спрямованих на врегулювання та контроль за доступом третіх осіб. Під третіми особами часто маються на увазі не представники сторонніх організацій, а саме власний персонал, який через специфіку службових обов'язків має повний, частковий чи нульовий доступ до такої інформації. Як зазначає Г. Малишева, у разі бездіяльності підприємства щодо вжиття заходів правової охорони за витоку чи іншого розголошення інформаціі воно позбавлене можливості захисту своїх прав та законних інтересів із використанням правоохоронних засобів, тобто права на судовий захист [11, с. 21]. Отже, відсутність чіткого врегулювання питання доступу до комерційної таємниці та режиму користування нею найманими працівниками позбавляє роботодавця можливості застосування дисциплінарних санкцій, зокрема оголошення догани та звільнення з посади за іiі розголошення.

Щодо комерційної таємниці у трудових відносинах, то в результаті проведеного аналізу чинного Кодекс законів про працю України, як уже зазначалося, ми не бачимо навіть згадки про таке явище, як комерційна таємниця. Він не містить ні чіткого переліку основних (додаткових) умов трудового договору, ні віднесення нерозголошення комерційної таємниці до однієї з них. Хоча інформація про наявність використання комерційної таємниці у процесі виконання посадових обов'язків має обов'язково бути закріплена під час укладення трудового договору. Адже внаслідок 
розвитку підприємництва в Україні та поширення конкуренції між суб'єктами підприємницької діяльності така додаткова умова трудового договору (про нерозголошення комерційної таємниці) набуває широкої популярності й актуальності. Хоча цей недолік частково усуває проєкт Трудового кодексу України, у ч. 3 ст. 32 якого до додаткових умов трудового договору віднесено «застереження щодо нерозголошення комерційної таємниці та іншої захищеної законом інформації». Подальшого розвитку дана норма набула у ст. 41 Проєкту «Умови трудового договору щодо нерозголошення державної, комерційної таємниці та іншої захищеної законом інформації, де зазначено, що «у разі прийняття чи переведення на роботу, що передбачає допуск до державної таємниці, працівник бере письмове зобов'язання щодо збереження державної таємниці. Розголошення державної таємниці тягне за собою встановлену законом відповідальність. Якщо працівник у зв'язку 3 виконанням трудових обов'язків має доступ до інформації, що відповідно до закону визнана комерційною таємницею або іншою захищеною законом інформацією, на вимогу роботодавця під час укладення трудового договору до нього включається умова про нерозголошення цієї таємниці або інформації в період трудових відносин i протягом визначеного сторонами строку після їх припинення, а також попередження про відповідальність за іiі порушення, встановлену законом. Ця умова може бути включена до трудового договору пізніше, у разі необхідності допуску працівника до такої інформації. При цьому відмова працівника включити відповідні умови до трудового договору за наявності в роботодавця права вимагати їх включення $є$ підставою для відмови у прийнятті на роботу, а якщо трудові відносини вже виникли - для їх припинення. У разі порушення працівником зобов'язань щодо нерозго- лошення комерційної таємниці або іншої захищеної законом інформації він несе відповідальність згідно із законом» [12].

Проте включення такої умови трудового договору має відбуватися 3 огляду на ст. 36 Господарського кодексу України, у ч. 1 якої поняття комерційної таємниці визначено як «відомості, пов'язані з виробництвом, технологією, управлінням, фінансовою та іншою діяльністю суб'єкта господарювання, що не є державною таємницею, розголошення яких може завдати шкоди інтересам суб'єкту господарювання, можуть бути визнані його комерційною таємницею» [13]. Оскільки без урахування положень зазначеної норми неможливо оцінити доцільність і правомірність такої умови, а отже, включення умов трудового договору, що забезпечують правила добросовісної конкуренції, завжди повинно спиратися на визначення комерційної таємниці. Зміна трудового договору шляхом включення нової умови про нерозголошення комерційної таємниці має бути зваженою, мотивованою і доцільною.

Висновок. У підсумку можна констатувати, що розгляд інституту комерційної таємниці крізь призму відносин роботодавця та найманого працівника дозволить глибше, грунтовніше зрозуміти сутність комерційної таємниці, їі місце в економічній безпеці підприємства, принципову відмінність від інших видів інформації з обмеженим доступом. Варто звернути увагу на декілька важливих моментів, а саме: обов'язок нерозголошення комерційної таємниці повинен бути належним чином визначений у корпоративних чи нормативних актах; інформація про наявність використання комерційної таємниці у процесі виконання посадових обов'язків має обов'язково бути закріплена під час укладення трудового договору; у роботодавця повинна бути реальна можливість дострокового припинення трудових відносин у разі порушення 
працівником вимог нерозголошення; наявність механізму відшкодування працівником збитків, завданих неправомірним розголошенням комерційної таємниці.

Комерційна таємниця у трудових відносинах - це відомості економічного, виробничого, технічного й організаційного характеру, що стали відомі працівникові через специфіку виконання посадових обов'язків та повинні зберігатися ним у таємниці, a їх розголошення повинне спричиняти для нього негативні наслідки відповідно до закону та норм укладеного договору. До характерних ознак комерційної таємниці варто віднести такі: закріплення обов'язку не розголошувати комерційну таємницю; інформація про наявність використання комерційної таємниці у процесі виконання посадових обов'язків має обов'язково бути закріплена під час укладення трудового договору; наявність у роботодавця реальної можливості дострокового припинення трудових відносин у разі порушення працівником вимог нерозголошення; наявність механізму відшкодування працівником збитків, завданих неправомірним розголошенням комерційної таємниці; можливість притягнення до різних видів юридичної відповідальної за скоєння працівниками під час виконання трудових функцій діянь, що посягають на правовий режим обігу комерційної таємниці.

У статті розглянуто понятmя та характерні ознаки, притаманні комериійній таємниці у трудових відносинах. Зроблено висновок, щи розгляд інституту комериійної таємниці саме крізь призму відносин роботодавия та найманого працивника дозволить глибше, трунтовніше зрозуміти сутність комериійної таємниці та iï місие в економічній безпеці підприємства, принципову відмінність від інших видів інформаціі з обмеженим доступом. Звернено увагу на декілька важливих моментів, а саме: обов'язок нерозголошення комериійної таємниці повинен бути належним чином визначений у корпоративних чи нормативних актах; інформація про наявність використання комериійної таємниці у процесі виконання посадових обов'язків має обов'язково бути закріплена під час укладення трудового договору; у роботодавия повинна бути реальна можливість дострокового припинення трудових відносин у разі порушення працівником вимог нерозголошення; наявність механізму відшкодування працівником збитків, завданих неправомірним розголошенням комериійної таємниці.

Комериійу таємницю у трудових відносинах розглянуто як відомості економічного, виробничого, технічного й організаційного характеру, які стали відомі працівникові через специфіку виконання посадових обов'язків та повинні зберігатися ним у таємниці, $a$ ïx розголошення має спричиняти для нього негативні наслідки відповідно до закону та норм укладеного договору. До характерних ознак комерційної таємниці віднесено такі: закріплення обов'язку не розголошувати комериійну таємницю; інформація про наявність використання комериійнӧ̈ таємниці у процесі виконання посадових обов'язків має обов'язково бути закріплена під час укладення трудового договору; наявність у роботодавия реальної можливості дострокового припинення трудових відносин у разі порушення працівником вимог нерозголошення; наявність механізму відшкодування працівником збитків, завданих неправомірним розголошенням комерційної таємниці; можливість притягнення до різних видів юридичної відповідальної за скоєння працівниками під час виконання трудових функцій діянь, щзо 
посягають на правовий режим обігу комериійної таємнициі.

Ключові слова: працівник, роботодавець, комерційна таємниця, трудові відносини, умова трудового договору, відповідальність.

Klymenko $V$. On the issue of commercial secrets in employment relations

The article considers the concepts and characteristics inherent in trade secrets in labor relations. It is concluded that the consideration of the institution of trade secrets through the prism of the relationship between employer and employee will provide a deeper, more thorough understanding of the essence of trade secrets and its place in economic security, a fundamental difference from other types of information with limited access. Several important points are highlighted, namely: the obligation not to disclose a trade secret should be properly defined in corporate or regulatory acts; information on the existence of the use of trade secrets in the performance of official duties must be specified when concluding an employment contract; the employer must have a real possibility of early termination of employment in case the employee violates the requirements of non-disclosure; the existence of a mechanism for compensation by the employee for damages caused by illegal disclosure of trade secrets.

Trade secret in labor relations is considered as information of economic, industrial, technical and organizational nature, which became known to the employee due to the specifics of the duties and must be kept secret, and their disclosure should cause him negative consequences in accordance with law and regulations of the concluded contract. The characteristic features of a trade secret include the following: stipulation of the obligation not to disclose a trade secret; information on the existence of the use of trade secrets in the performance of official duties must be fixed at the conclusion of the employment contract; the employer has a real possibility of early termination of employment in case the employee violates the requirements of non-disclosure; the existence of a mechanism for compensation by the employee for damages caused by illegal disclosure of trade secrets; the possibility of bringing to various types of legal responsibility for the commission by employees during the performance of labor functions of acts that encroach on the legal regime of trade secrets.

Key words: employee, employer, trade secret, labor relations, condition of employment contract, responsibility.

\section{Література}

1. Кузнецова Х. Характеристика комериійнӧ̈ таємниці як інституту права. Наукові праці Міжрегіональної Академії управління персоналом. 2010. Bun. 3 (26). C. 204.

2. Сляднева A. Определение понятия коммерческой тайны субъекта хозяйствования. Підприємство, господарство i право. 2004. № 9. С. 40-43.

3. Економічна енциклопедія: у 3-х $\mathrm{m}$. / гол. ред. Б. Гаврилишин. Київ : Вид. иентр «Академія», 2000. T. 1.863 с.

4. Справочник директора предприятия / под ред. М. Лапустьл. 6-е изд., испр., измен. и доп. Москва : Инфра-М, 2003. 912 c.

5. Жилинский С. Предпринимательское право: правовая основа предпринимательской деятельности : учебник. Москва: Норма, 2007. 944 с.

6. Юсупова Д. Комериійна таємниця як об'єкт трудових відносин: поняття та ознаки. Публічне право. 2013. № 2 (10). C. 336-343.

7. Правове та законодавче забезпечення економічної безпеки України : монографія / за ред. А. Гетьмана, Є. Білоусова, Г. Анісімової. Харків : Право, 2017. $336 \mathrm{C}$.

8. Андрощук Г., Вороненко Л. Какие сведения могут составлять коммерческую тайну. Бизнес Информ. 1999. № № 9-10. C. 12-18. 


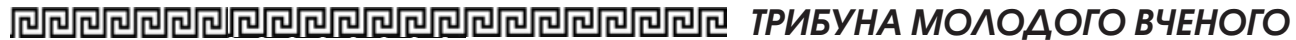

9. Интеллектуальная собственность в Украине : правовые основы и практика / под общ. ред. А. Святоикого. Киев : Iн Юре, 1999. T. 3. 672 с

10. Носік Ю. Зміни у правовому режимі комериійнӧ̈ таємниці за новим інформаційним законодавством України. П’яті цивілістичні читання, присвячені 85-річчю із Дня народження професора О.А. Підопригори, 31 березня 2011 р. Київ : ВПЦ «Київський універсиmem», 2012. C. 172-177.
11. Мальщева Г. Коммерческая тайна в зеркале закона. Право и экономика. 1999. № 10. С. 20-24.

12. Проект трудового кодексу Украіни, реєстр. № 1658, текст доопраиьований від 20 травня 2015 p. URL: http: / / 1.c1.rada.gov.ua/pls / zweb2 / webproc4_1?pf3511=53221.

13. Господарський кодекс України Закон від 16 січня 2003 р. № 436-IV. Відомості Верховної Ради України. 2003. № № 18-22. Cm. 144 . 